\title{
Miért érdemes a Fradinak szurkolni a Groupama Arénában?
}

\author{
Borbola József', Sári Csaba', Som Zoltán', Suhai Ferenc², Csepregi András ${ }^{1}$
}

\author{
${ }^{1}$ Gottsegen György Országos Kardiológiai Intézet, Felnőtt Kardiológiai Osztály, Budapest \\ ${ }^{2}$ Semmelweis Egyetem, Városmajori Szív- és Érgyógyászati Klinika, Budapest \\ Levelezési cím: \\ Dr. Borbola József, 1450 Budapest, Postafiók 88. E-mail: borbola@kardio.hu
}

\begin{abstract}
A 29 éves Fradi-szurkoló egy izgalmas Fradi futballmeccs szünetében abortált, hirtelen szív(aritmia)halált szenvedett, a helyszínen lévő OMSZ mentőegysége sikeresen reszuszcitálta a Groupama Aréna nézőterén. Az esemény hátterében kardiológiai kivizsgálása egy ritka szívizombetegség entitásra, aritmogén bal kamrai cardiomyopathiára (ALVC-re) derített fényt. Az ALVC egy ritka, örökletes, elsősorban a desmosomális vagy extradesmosomális proteineket kódoló gének mutációján alapuló, fiatalkori hirtelen szív(aritmia)halált okozható progresszív szívizombetegség-variáns. Erre a típusra a klasszikus aritmogén jobb kamrai cardiomyopathia kritériumai nem alkalmazhatók. Az ALVC-re jellemző föbb eltérések a következők: 1. EKG-n T-hullám-inverzió az (infero)laterális elvezetésekben; 2. szív-MR-vizsgálatok nem (vagy enyhén) dilatált, fibrotikus bal kamrát mutatnak, enyhe szisztolés diszfunkcióval, nagy kiterjedésű, bal kamrai főként inferolaterális, septalis szubepikardiális, mid-miokardiális (nem-iszkémiás jellegü) késői gadolinium-halmozással, normál jobb kamra; 3. bal kamrai eredetű ritmuszavarok; 4. fokozott hajlam fiatalkori kamrafibrillációra.
\end{abstract}

A fiatal Fradi-szurkoló kardiológiai kivizsgálása ALVC-t igazolt. Kezelése életmód-változtatásból (a stresszes sportaktivitások korlátozása), a kamrai ritmuszavarok csökkentéséből (adrenerg béta-blokkoló kezelés), valamint a hirtelen szív(aritmia)halál prevenciójából (szekunder prevenciós ICD-implantáció) állt.

A fiatalkori abortált hirtelen szív(aritmia)halál kivizsgálása kapcsán gondolni kell az aritmogén ventrikuláris cardiomyopathia ritka, nem-klasszikus variánsára, csak a bal kamrát dominánsan érintő ALVC-fenotípusra is.

Az új Groupama Aréna biztonságos sportlétesítmény nemcsak a játékosok, hanem a nézőtéri szurkolók szempontjából is.

Kulcsszavak: aritmogén ventrikuláris cardiomyopathia, aritmogén bal kamrai cardiomyopathia, szív-MR-imaging, fiatalkori hirtelen szív(aritmia)halál

Is it worth while to be a fan of Fradi in the Groupama Arena?

A 29 years old Fradi-fan suffered aborted sudden cardiac (arrhythmic) death during the half-time of an exciting Fradi football game in the Groupama Arena. The fan was successfully resuscitated by the OMSZ ambulance team on the spot. In the background of this event, the cardiological, clinical work-up of the fan revealed a rare, left ventricular myocardial disease entity, namely the arrhythmogenic left ventricular cardiomyopathy (ALVC).

The ALVC is a progressive myocardial arrhythmogenic disease based on the mutations of mostly desmosomic and extradesmosomic proteins encoding genes, which is capable of inducing ventricular fibrillation in the young. The criteria of the classical forms of the arrhythmogenic right ventricular cardiomyopathy cannot be applied to his variant phenotype The main distinctive features of the dominant ALVC variant are as follows: (1) ECG T wave inversions in the (infero)laterals leads; (2) cardiac MR morpho-functional imaging is consistent with a left ventricle showing mild systolic dysfunction, no (or mild) dilatation, and a great amount of inferolateral, septal, subepicardial/mid-myocardial (non-ischemic type) late gadolinium enhancement. Normal right ventricle; (3) ventricular arrhythmias reflecting the origin from the left ventricle; (4) increased susceptibility to cardiac arrest by ventricular fibrillation at a young age. The hospital work-up of this young Fradi-fan verified the ALVC entity. Treatment strategies focused on lifestyle modifications (restriction of stressful sport activity), controlling arrhythmias with adrenerg betablocker therapy and preventing sudden cardiac (arrhythmic) death with an ICD.

In connection with the clinical diagnostic work-up of aborted sudden cardiac (arrhythmic) death in a young person, one should think of this rare, non-classical, arrhythmogenic ventricular cardiomyopathy subtype (ALVC), predominantly effecting the left ventricle. The new Groupama Arena is proved to be a safe sport establishment not only for the football players, but also for the spectators.

Keywords: arrhythmogenic ventricular cardiomyopathy, arrhythmogenic left ventricular cardiomyopathy, cardiac MR imaging, sudden cardiac (arrhythmic) death in the young

A kézirat 2020. 06. 19-én érkezett a szerkesztőségbe, 2020. 07. 29-én került elfogadásra. 


\section{Bevezetés}

A fiatal élsportolók sportesemény alatti váratlan keringésleállása, hirtelen szív(aritmia)halála a családot és a közvéleményt erősen megrázó, tragikus esemény $(1,2,3)$. Ezután általában mindenkiben, minduntalan felmerül az a kérdés, hogy az élsportolónak milyen rejtett, fel nem ismert szívbetegsége lehetett, milyen háttérben lévő történések vezethettek a szomorú végkifejlethez, a szív elektromos katasztrófájához. A reflektorfénybe kerülö, hivatásos sportolóval szemben a közvélemény, a médiacsatornák és a szakértők is sokkal kevéssé foglalkoznak az ugyancsak sporteseményen, de nem a pályán, hanem a nézőtéren a szurkolók között bekövetkezö hirtelen szívhaláleseményekkel.

Jelen közleményünk célja az, hogy ismertesse a Fradi híres „B-közép” szurkolótáborához tartozó fiatal futballrajongónak a Groupama Aréna nézőterén, egy izgalmas mérkőzés alatt bekövetkezett, de sikeresen reszuszcitált, abortált hirtelen szív(aritmia)halálát, valamint annak hátterében megbújt ritka szívbetegséget.

\section{Esetismertetés}

Egy hideg márciusi szombat este egy 29 éves $(80 \mathrm{~kg}$, $187 \mathrm{~cm}$ ) fanatikus Fradi-szurkoló férfit hozott az OMSZ felvételre a Gottsegen György Országos Kardiológiai Intézet koronáriaőrzőjébe kamrafibrilláció (KF) miatt sikeresen reszuszcitált, reanimált állapotban a szomszédos Groupama Arénából. A Fradi-Puskás Akadémia futballmeccs félidejében, a szünet elején, a szurkolás után a férfi felállt, szédülésről, fejfájásról panaszkodott, majd élettelenül visszaesett a lelátó széksorára. A B-közép alatt állomásozó OMSZ-mentőautó személyzete a segélykiáltásokra gyorsan odaért: keringés- és légzésleállást, KF-et állapítottak meg. Négyszeri defibrillálás, gyógyszeres kezelés (Tonogen $1 \mathrm{mg}$, amiodaron 300 mg iv.), 20-30 perces reanimáció után állapota stabilizálódott, sinusritmusa tartósan visszatért. Érkezéskor az intubált, lélegeztetett beteg hemodinamikailag stabil, kardiorespiratorikusan kompenzált állapotban volt alacsony dózisú vazopresszor támogatással. Fizikális vizsgálattal szedált állapota mellett lényegében negatív státuszt észleltünk. Az érkezési, nyugalmi 12 elvezetéses EKG-n normofrekvenciás sinusritmus ábrázoló-

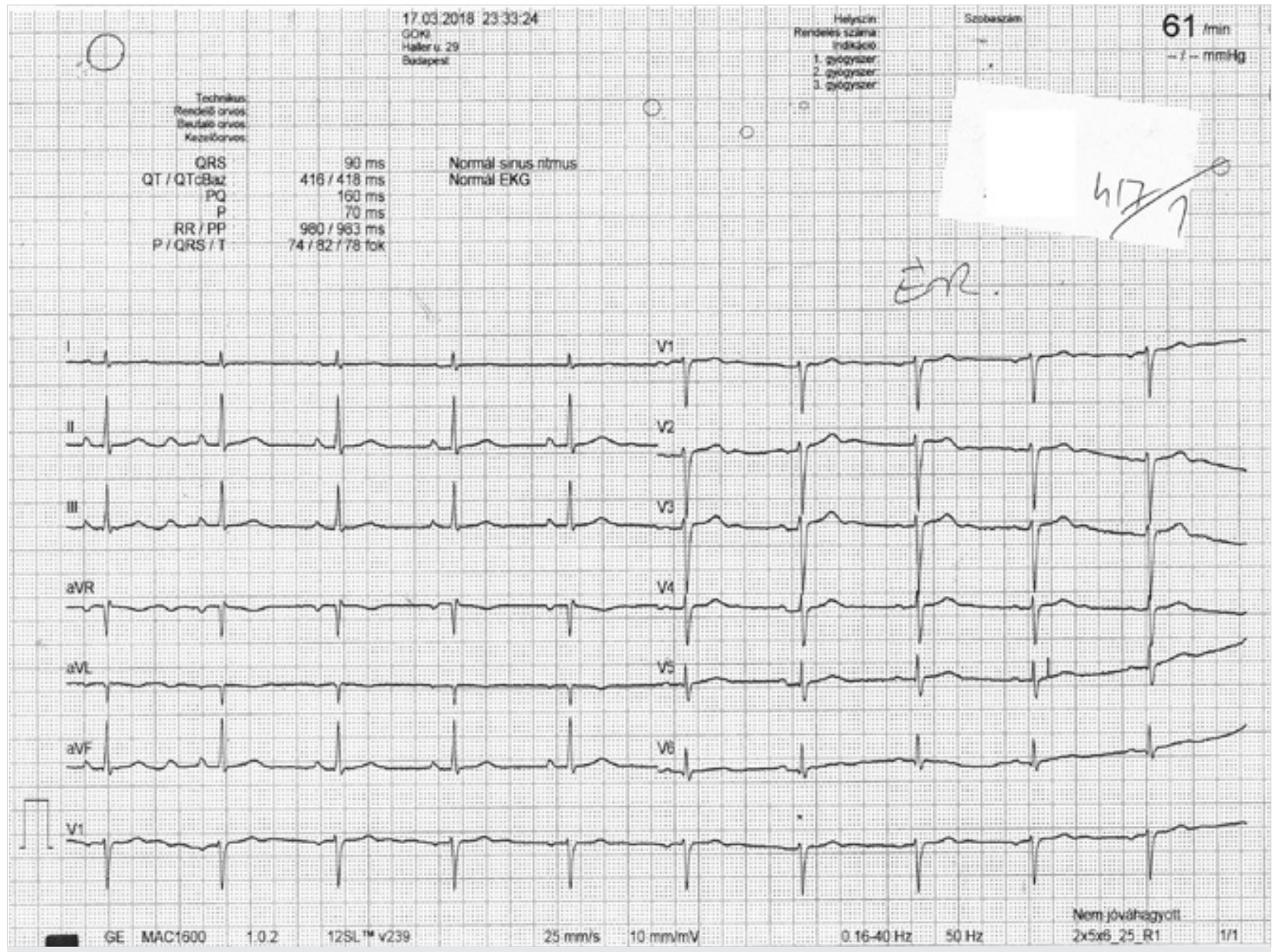

1. ÁBRA. A Fradi-szurkoló felvételi EKG-ja (62/min sinusritmus, normál EKG). A $V_{2}$ - $\mathrm{V}_{3}$-elvezetésekben az S-hullám kicsit szélesebb (50 msec), de a QRS $90 \mathrm{msec}$ 
dott, a $\mathrm{V}_{2}-\mathrm{V}_{3}$-elvezetésekben kissé kiszélesedő „s”-hullámokkal (1. ábra).

Családi kórelőzményében az anyai nagymama fiútestvére 27 éves korában éjszaka hirtelen halállal halt meg. Egyéni anamnézisében számottevő korábbi betegség, gyógyszerszedés nem szerepelt. Nem dohányzott. Rendszeresen sportolt, amatőr szinten futballozott. A meccs napján délután autóval érkezett vidékről Budapestre, alkoholt, energiaitalt aznap nem fogyasztott. Előző napon hegyvidéki kiránduláson vett részt, a távot panaszmentesen teljesítette. Elmondta, hogy 2-3 éve szokott időszakosan érezni hevesebb szívverést, „extrázást”, különösen stresszes időszakban. Egy évvel korábban volt egy órákig tartó gyors szívveréssel járó rosszulléte, EKG nem készült. Emiatt kardiológus is vizsgálta, de a kivizsgálás abbamaradt, mivel ez a panasza később megszünt magától.

A felvételi laborokból emelkedett kardiális nekroenzimszintek (CK: 2358 U/I, CKMB: 94 U/L, TnT: 607,2 ng/l), normális CRP, elektrolitszintek, vérkép, vesefunkció emelendők ki. A szívizom-iszkémia, koronáriaanomália kizárása céljából elvégzett koronarográfia ép koszorúsérrendszert igazolt. A hipotermiás kezelés, extubálás utáni echokardiográfiás vizsgálata megtartott szisztolés balkamra-funkciót (EF: 50\%) írt le, ép billentyűket, normál jobbszívfelet. Szegmentális falmozgászavar, perikardiális folyadék nem volt. Más alkalommal ké- szített EKG-felvételein normofrekvenciás sinusritmus mellett inferolaterális T-hullám-negativitás, inverzió volt észlelhetö (2. ábra).

Az alapbetegség tisztázása céljából felvétele után egy héttel szív-MR- (Philips Achieva 1.5 T) vizsgálatra került sor. Az MR-vizsgálat enyhén csökkent bal kamrai ejekciós frakciót (EF: 48,7\%), normál bal kamrai végdiasztolés és végszisztolés volument, normál bal kamrai izomtömeget, a bal kamra csúcsi hipokinezisét írta le. Jó jobb kamrai ejekciós frakció (EF: 52,3\%), normál jobb kamrai végdiasztolés és végszisztolés volumenek, jó verővolumen ábrázolódott. A SPIR-felvételeken miokardiális ödémára utaló egyértelmü fokozott szignálintenzitás nem volt. Kontrasztanyag iv. beadását követően késői típusú kontraszthalmozás alakult ki a bal kamra csúcsában és csúcsi anterior-anteroseptalis részén szubepi-midmiokardiális jelleggel, valamint a csúcsi laterális és kp. harmad inferolaterális szegmentumában szubepikardiálisan. A bal kamra csúcsában anterior falon perikardiális halmozás volt látható. Kórjelző halmozás a jobb kamrai izomzatban nem alakult ki. Vélemény: enyhe fokban csökkent bal kamrai ejekciós frakció, normál kamravolumenek. A laterális falon és a csúcsban aspecifikus késői halmozás ábrázolódott. A myocardium 17,5\%-a érintett. $A z$ etiológia kérdéses, akár lezajlott myocarditis vagy sarcoidosis is felmerülhet, de a késői halmozás mennyi-

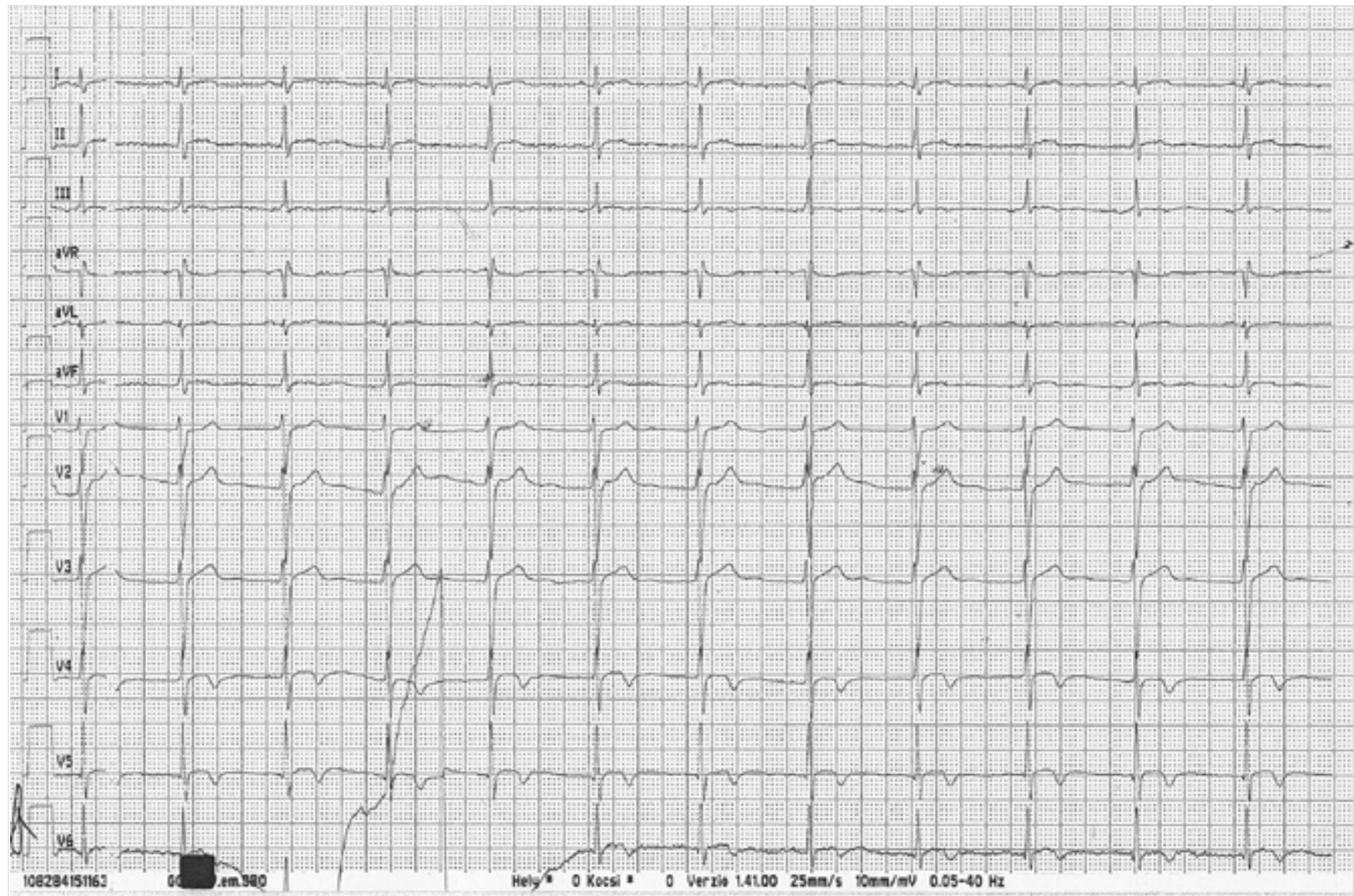

2. ÁBRA. A Fradi-szurkoló elbocsátási EKG-ja (67/min sinusritmus, $\mathrm{V}_{4}-\mathrm{V}_{6}$ elvezetésekben negatív T-hullámok) 


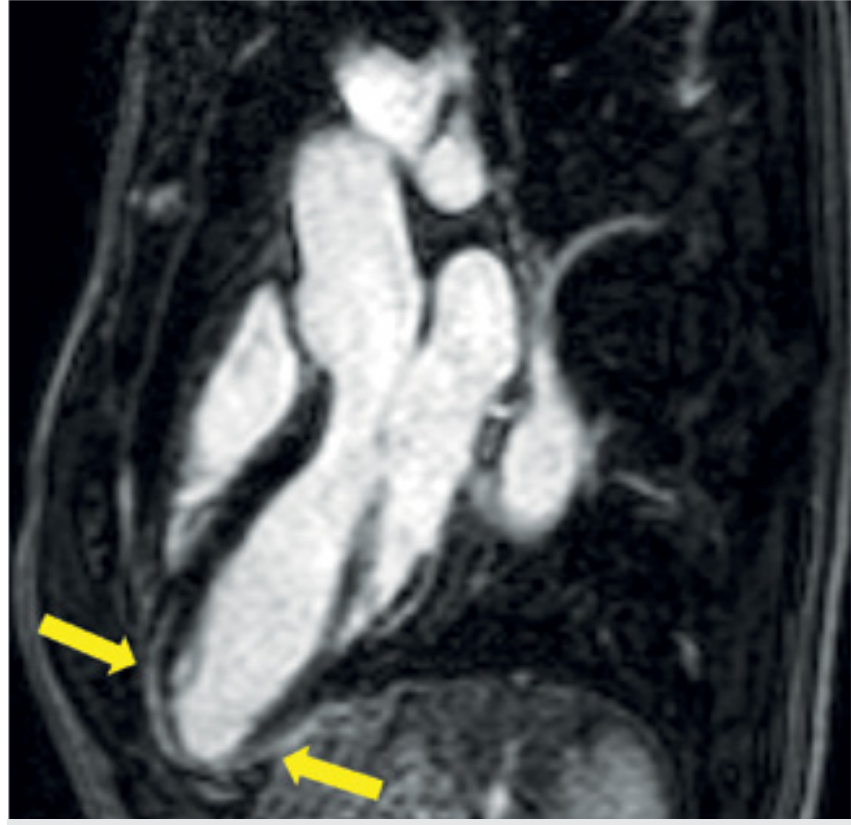

3. ÁBRA. 3 üregi késői halmozásos szív-MR-kép. Jól látható a csúcsban csaknem körkörös szubepi-midmiokardiális lokalizációjú késői kontraszthalmozás (sárga nyilak)

sége, illetve a mintázata ALVC mellett szól (3., illetve 4. ábra).

Felvétele után tíz nappal MR-kondicionális szekunder prevenciós implantábilis cardioverter-defibrillátor (ICD) készülék (Boston Scientific Dynagen Mini VVICD) és elektróda (Boston Scientific Endotak Reliance SG) implantációját végeztük el a bal subclavicularis régióban. (Jobb lett volna jobb oldalra helyezni az ICD-t, a kontroll MR-vizsgálatokat zavaró hatások csökkentése miatt.) Az ICD VVI 40/min pace, KT: 188/min, KF: 220/min paraméterekkel került programozásra. Az ICD-implantáció után a Fradi-szurkoló panaszmentesen hazabocsátásra került nebivolol $(2 \times 2,5 \mathrm{mg} / \mathrm{nap})$ kezeléssel, amelyet később maximális dózisig titrált bisoprololra ( $2 \times 5 \mathrm{mg} / \mathrm{nap})$ cseréltünk.

\section{Utánko̊vetés}

ICD: Az implantáció után 18 hónappal egy KF-epizódot szüntetett meg a Boston Dynagen Mini ICD.

Kontroll szív-MR-(Siemens Magneton Aera 1,5 T) vizsgálat: $A z$ ICD-telep okozta mütermékek miatt erősen korlátozott diagnosztikus értékủ vizsgálat. A volumetriás kiértékelés és a falmozgások megítélése nem lehetséges. A késői kontraszthalmozásos felvételeken a 15 hónappal korábban leírt kp. harmad inferolaterális szegmentumában a szubepikardiális halmozás változatlan, a csúcsi harmad és a csúcs a mütermékek miatt nem megítélhetőek. A mütermékmentes jobb kamrai izomzatban, illetve a pericardiumban késői típusú kontraszthalmozás nem alakult ki. A két, összehasonlító szív-MR-vizsgálat főbb eredményeit az 1. táblázatban tüntettük fel.

Holter (nebivolol 2×2,5 mg/nap mellett): 40-121 (64)/ min sinusritmus, $897 \mathrm{KES} / 24$ óra, néhány salve. Normál HRV- és QT-diszperzió.

Terheléses EKG (nebivololkezelés mellett): $150 \mathrm{~W} 1$ perc terhelhetőség. Panasz, EKG-eltérés, szívritmuszavar nem volt. Normális vérnyomásválasz.

Genetikai vizsgálat (Penta Core Lab Kft., kardiológiai komplett panel NGS alapú vizsgálat): a vizsgálat a CLCN1-génben azonosított egy heterozigóta patogén mutációra pozitív eltérést (p.Arg894Ter), amely szinte

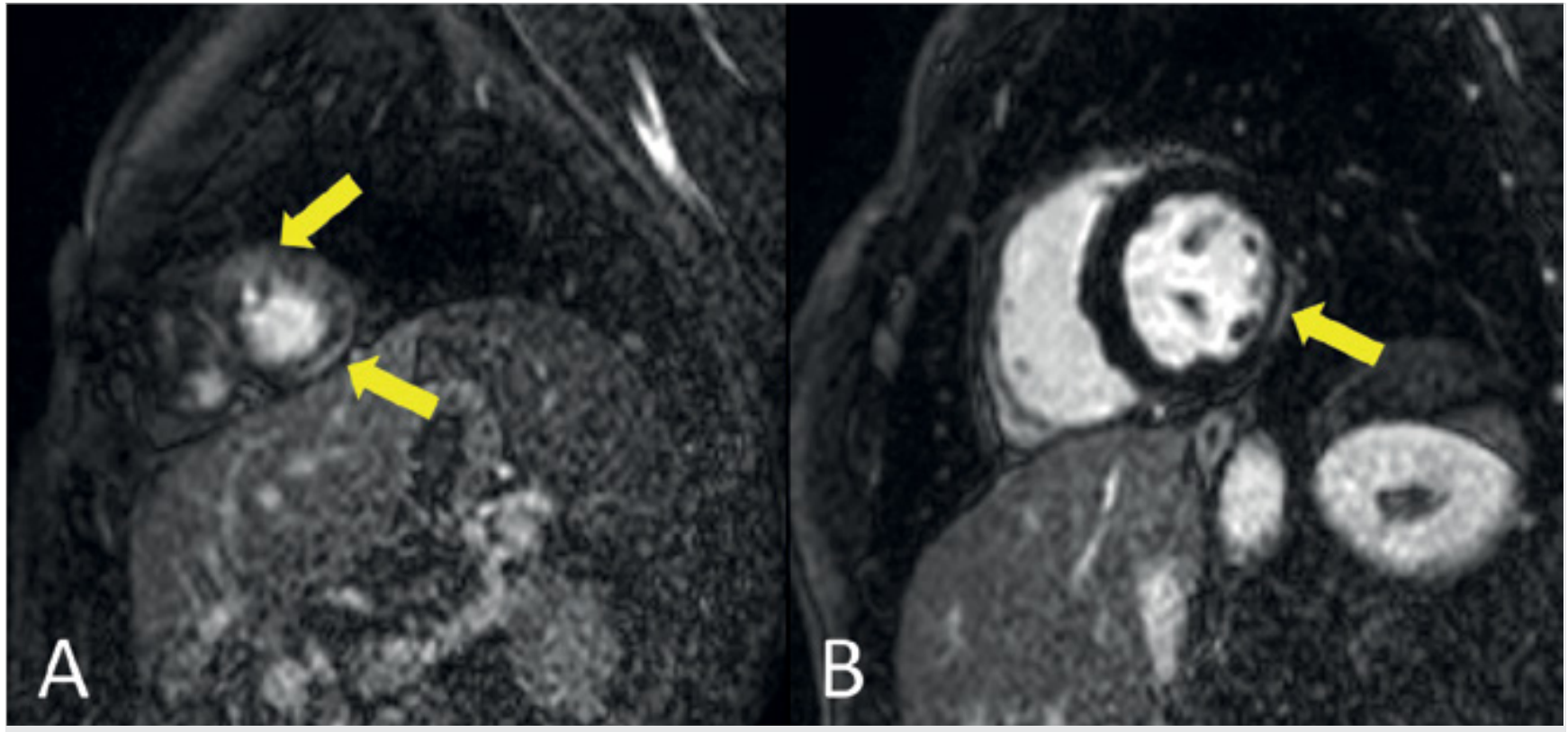

4. ÁBRA. A: kiterjedt, csaknem körkörös szubepi-midmiokardiális lokalizációjú késői kontraszthalmozás látható (sárga nyilak).

B: A bal kamra középső harmad inferolaterális szegmentumában szubepikardiális késői halmozás látható (sárga nyíl) 
1. TÁBLÁZAT. A szív-MR-vizsgálatainak föbb eredményei (A bal oldali ICD-telep okozta mütermékek miatt a kontrollvizsgálatkor a volumetriás kiértékelés és a falmozgások, valamint a késői típusú kontraszthalmozás pontos megítélése a csúcsi, csúcsi anteroseptalis és csúcsi anterior falon nem lehetséges, ezeket - jel jelöli)

\begin{tabular}{|c|c|c|}
\hline \multicolumn{3}{|c|}{ Szív-MR-vizsgálatok } \\
\hline $\begin{array}{l}\text { Vizsgált para- } \\
\text { méter }\end{array}$ & $\begin{array}{l}\text { Akut szív-MR-vizs- } \\
\text { gálat (2018.03.26) }\end{array}$ & $\begin{array}{l}\text { Kontroll } \\
\text { szív-MR- } \\
\text { vizsgálat } \\
\text { (2019.07.15) }\end{array}$ \\
\hline $\begin{array}{l}\text { LVEF }(\%) \\
\text { LVESVi }\left(\mathrm{ml} / \mathrm{m}^{2}\right) \\
\text { LVEDVi }\left(\mathrm{ml} / \mathrm{m}^{2}\right) \\
\text { LVMEDi }\left(\mathrm{g} / \mathrm{m}^{2}\right)\end{array}$ & $\begin{array}{l}48,7 \\
43,2 \\
84,4 \\
67,8\end{array}$ & $\begin{array}{l}- \\
- \\
- \\
-\end{array}$ \\
\hline $\begin{array}{l}\text { RVEF }(\%) \\
\text { RVESVi }\left(\mathrm{ml} / \mathrm{m}^{2}\right) \\
\text { RVEDVi }\left(\mathrm{ml} / \mathrm{m}^{2}\right)\end{array}$ & $\begin{array}{l}52,3 \\
37,0 \\
77,6\end{array}$ & $\begin{array}{l}- \\
- \\
-\end{array}$ \\
\hline SPIR & ödéma AE & - \\
\hline
\end{tabular}

Gadolinium iv. beadás után

Bal kamra Késői típusú halmozás $\quad \begin{aligned} & \text { Késői típusú } \\ & \text { halmozás }\end{aligned}$

Csúcsi, csúcsi anterioseptalis, szubepi-midmiokardiális jelleggel

Csúcsi laterális és $\mathrm{kp}$. harmad inferolaterális szegmentumban szubepikardiálisan

Csúcsi anterior falon perikardiálisan

Jobb kamra Nincsen Nincsen

kizárólag vázizomzatot érintő betegség okaként ismert. ARVC hátterében ismert 13 gén egyikében sem igazolódott patogén eltérés.

Kontroll echo-vizsgálat: szegmentális falmozgászavar nincsen, jó szisztolés balkamra-funkció. Normál jobbszívfél.

\section{Megbeszélés}

A 29 éves Fradi-szurkoló egy izgalmas Fradi futballmeccs szünetében abortált, hirtelen szív(aritmia)halált szenvedett a Groupama Arénában. A helyszínen lévő OMSZ mentőegysége a nézőtéren sikeresen reszuszcitálta. A kialakult KF hátterében kardiológiai kivizsgálása egy ritka bal kamrai szívizombetegség entitásra, az aritmogén bal kamrai cardiomyopathiára (ALVC-re) derített fényt $(4,5,6,7,8)$.

$A z$ aritmogén ventrikuláris cardiomyopathia (AVC) egy ritka, örökletes, elsősorban a desmosomális proteineket kódoló gének mutációján alapuló, fiatalkori hirtelen szív(aritmia)halált okozható progresszív szívizombetegség $(9,10,11)$. Az AVC hisztopatológiai szubsztrátja a myocyták közötti elektromechanikus kapcsolatok károsodása, a jelátviteli utak, a gap-junction-ok megszaka- dása, a desmosomális integritás elvesztése, amelyek a szívizomsejtek atrófiájához, nekrózisához vezetnek. Ez a folyamat zsíros-kötőszövetes átépüléssel, hegesedéssel jár az epicardium felöl az endocardium irányába (ún. wavefront fenomén), amely idővel transmuralissá is válhat. A szívizomsejtek közötti zsíros-fibrotikus szövetek, szigetek alig vezetik az elektromos impulzusokat, az elektromos szinkronitás károsodik, ezért ezek a területek a kamrai ritmuszavarok kiindulási gócaivá válnak $(10,11)$. Az életveszélyes kamrai tachyaritmiák kiindulásához hozzájárul a ventrikuláris szimpatikus innerváció zavara is (12), valamint az esetek nagy részében kimutatható miokardiális lokális gyulladásos infiltráció is $(10,11)$. Az AVC természetes lefolyását periodikus akut burst-ök, gyulladásos epizódok fellángolásai ronthatják, amelyek az alapbetegség további progressziójához vezetnek. Az AVC-re jellegzetes, hogy a kamrai ritmuszavarok fizikai/mentális stresszre indulnak be, életkor-specifikusak: fiatalabb életkorban akut elektromos instabilitás, KF bekövetkezése észlelhető föként, míg idősebb korban re-entry talaján tartós, monomorf kamrai tachycardiás epizódok a jellemzőek $(9,10,13)$. A klasszikus, elsőként leírt jobb kamrai, az ún. diszpláziás háromszög érintettségével járó ARVD diagnózisa a 2010-ben közzétett, 2018-ban ismét áttekintett, módosított kritériumrendszer (ún. major és minor kritériumok) alapján történik $(14,15)$. A kritériumok noninvazív és invazív tesztek eredményei, amelyek a jobbkamra-funkció és struktúra, valamint az elektromos müködés megítélésére szolgálnak $(11,14,15)$.

A jobb kamrai aritmogén cardiomyopathiához (ARVC-hez), vagy újabb nevén a jobb kamrai aritmogén diszpláziához (ARVD) azonban előbb-utóbb mindig társul a bal kamra érintettsége is (ún. biventrikuláris forma), sőt leírták a dominánsan, csak a bal kamrát érintő, igen ritka fenotípust (ALVC) is. Ezen utóbbi, nem-klaszszikus variánsok azonosításában, klinikai diagnosztikájában az ARVC/ARVD-re kidolgozott Task Force kritériumrendszer szenzitivitása azonban jelentősen csökkent értékű $(10,11,15)$. Az AVC-szakértök szerint az ALVC előfordulása meglehetősen ritka, pontos diagnosztikus kritériumai még hiányoznak, ezért felismerése kihívást jelent a kardiológusok számára, különösen a betegség korai ún. concealed, preklinikai fázisában. Azonosítása viszont azért is fontos, mivel még jó balkamra-funkció mellett is sokkal gyakoribb a korai, hirtelen szív(aritmia)halál, mint a klasszikus ARVC/ARVDben $(4,5,8,11,16,17)$.

A szív-MR-vizsgálat hatékony, korszerü képalkotási módszer már a korai szakban is a falmozgászavarok, a szívüregek nagyságának, funkciójának a pontos megítélésére. A szövet-karakterizációs technikákkal, a késői gadolinium-halmozásos képeken jól vizsgálható a zsíros-fibrotikus eltérések szívizomzatbeli jelenléte, eloszlása, mintázata, mennyisége, milyensége $(18,19$, 20, 21). Sen-Chowdry és munkatársai (5) 2008-ban számoltak be ALVC-ben szenvedő 42 beteg klinikai di- 
agnosztikai jellegzetességeiről. A szív-MR-vizsgálatnál jellemzőnek találták, hogy a betegek több mint a felének a septuma volt érintett, míg biventrikuláris AVCben a septum általában megkímélt. $A$ zsíros-fibrotikus hegesedés eloszlását föként inferolaterálisan a szubepikardiális és mid-miokardiális bal kamrai rétegekben írták le.

Szakértői vélemények, újabb vizsgálatok eredményei alapján az ALVD-fenotípusoknak az alábbi megkülönböztető jellemzőit, jegyeit javasolják $(4,5,7,8,11,17)$ :

1. A szív-MR-vizsgálat jellegzetessége a nem (vagy alig) dilatált, fibrotikus bal kamra, enyhe szisztolés diszfunkcióval nagy mennyiségü szubepikardiális/mid-miokardiális (nem-iszkémiás jellegü) késői gadolinium-halmozással föként a bal kamrai inferolaterális régióban. ALVC-re 100\%-ban specifikusnak találták, ha a bal kamra zsíros-fibrotikus szövetmenynyisége $\geq 20 \%$-a a bal kamrai izomtömegnek. Esetünkben ez az arány 17,5\%-nak adódott. A jobb kamra ép, érintetlen.

2. EKG: T-hullám-inverzió az (infero)laterális elvezetésekben (II-III-aVF és/vagy $V_{4}-V_{6}$ );

3. a jobb kamra-bal kamra volumen arány kisebb, mint 1 ;

4. bal kamrából eredő kamrai ritmuszavarok;

5. Holteren nagy mennyiségü kamrai extraszisztolé, gyakori nem tartós, monomorf kamrai tachycardiák;

6. fokozott hajlam a fiatalkori, korai kamrafibrillációra akár a betegség concealed, preklinikai fázisában;

7. az ALVC esetközlésekben desmosomális (desmoplakin) (4), plakophillin-2 $(4,21)$ és extradesmosomális (filamin C) (11), valamint transzmembrán protein43, és phospholamban (17) génmutációkat is leírtak;

8. alacsony QRS voltage $(<0,5 \mathrm{mV})$ a végtagi elvezetésekben a betegség elörehaladtával.

A bemutatott Fradi-szurkoló betegünknél az ALVC diagnózisát az alábbi jellemzők alapján állítottuk fel: pszichés stresszre kialakult, hirtelen szív- (KF) halál, családi kórelőzményben fiatalkori szívhalál, intermittáló, jellegzetes EKG-kép (negatív T-hullámok az inferolaterális EKG-elvezetésekben), nem dilatált, enyhén csökkent szisztolés funkciójú bal kamra (EF: 48\%), jellegzetes szív-MR-vizsgálati lelet: a csúcsi, anteroseptalis és inferolaterális régiókban nagy mennyiségü, nagy kiterjedésü szubepikardiális/mid-miokardiális késői gadolinium-halmozás, a jobb kamrai-bal kamrai volumen arány kisebb mint $1(0,9)$, a jobb kamra érintetlen, JTSZB mintájú gyakori kamrai extraszisztolék, gyakori nem tartós kamrai tachycardiák (ICD-Holter).

A genetikai, rutin komplett kardiológiai génpanel hazai vizsgálat megerősítést nem nyújtott a desmosomális vagy nondesmosomális génmutációkkal kapcsolatban. Ismert azonban az is, hogy a jelenlegi módszerekkel az esetek mintegy felében genetikai eltérés nem mutatható ki $(4,9,10,11,15,17,22)$.

Az ALVC mellett differenciáldiagnosztikai szempontból felmerült az önálló myocarditis, fibrózis és/vagy zsírdepozícióval járó más betegségek, pl. bal kamrai dilatatív cardiomyopathia, bal kamrai posztinfarktusos állapot, idiopátiás bal kamrai fibrózis, sarcoidosis, Duchenne-féle muscularis dystrophia (distrophin mutáció) is (8, 10, 11, 17). Ezen betegségek lehetőségeit azonban az extrakardiális manifesztációk hiánya, a klinikai kép és az elvégzett vizsgálataink, különösen a szív-MR-kép és -mintázat eredményei alapján kizártuk. Az ALVC prognózisát az ARVC/D-hez hasonlóan elsősorban a fatális kamrai ritmuszavarra, a hirtelen szívhalálra való hajlam, később szívelégtelenség kialakulása, progressziója befolyásolja. A fiatalkori abortált hirtelen szív(aritmia) halál kardiológiai kivizsgálása kapcsán gondolni kell erre a ritka bal kamrai szívizombetegség entitásra, az ALVC-fenotípusra is. Tudomásunk szerint ez az első hazai ALVC-esetközlés.

Esetismertetésünk azt is bizonyítja, hogy az új, 2014ben átadott Groupama Aréna biztonságos sportlétesítmény, megfelel a FIFA sportegészségügyi előirásainak, nemcsak a játékosok, hanem a nézők szempontjából is $(2,23,24,25)$. Minden futballmeccsen a pálya két oldalán egy-egy OMSZ-mentőegység van deponálva (egyik a B-közép alatt). Emellett a főépületben állandóan egy, a laikusok által is használható, automata externális cardioverter-defibrillátor is elhelyezésre került. Fradi-szurkoló betegünk a B-középpel együtt béta-blokkoló és ICD-protekció mellett nemrégen ünnepelte a Fradi 30. és 31. hazai bajnoki címét a Groupama Arénában.

Végül válasz a címben feltett kérdésre: miért is érdemes a Fradinak szurkolni a Groupama Arénában? Nemcsak a klasszis, BL-szintü futball miatt, hanem azért is, mert a Groupama Aréna orvosilag is biztonságos sportlétesítmény.

\section{Nyilatkozat}

A szerzők kijelentik, hogy az esetismertetés megírásával kapcsolatban nem áll fenn velük szemben pénzügyi vagy egyéb lényeges összeütközés, összeférhetetlenségi ok, amely befolyásolhatja a közleményben bemutatott eredményeket, az abból levont következtetéseket vagy azok értelmezését.

\section{Irodalom}

1. Chandra N, Bastianen R, Papadakis M, et al. Sudden cardiac death in young athletes. J Am Coll Cardiol 2013 62: 1027-1040.

https://doi.org/10.1016/j.jacc.2012.08.1032

2. Borbola J. A világbajnok halála. Cardiol Hung 2014; 44: 122-126. 3. Borjesson $\mathrm{M}$, et al. Consensus document regarding cardiovascular safety at sport arenas. Position stand from the European Association of Cardiovascular Prevention and Rehabilitation (EACPR) section of Sports Cardiology. Eur Heart J 2011; 32: 2119-2124. 4. Norman M, Sipson M, Mogensen J, et al. Novel mutation in desmoplakin causes arrhythmogenic left ventricular cardiomyopathy. Circulation 2005; 112: 636-642.

https://doi.org/10.1161/CIRCULATIONAHA.104.532234

5. Sen-Chowdry S, Syrris P, Prasad SK, et al. Left dominant arrhythmogenic cardiomyopathy: an underrecognized clinical entity. J Am Coll Cardiol 2008; 52: 2175-2182.

6. Saguner AM, Buchmann B, Wyler D, et al. Arrhythmogenic left 
ventricular cardiomyopathy: suspected by cardiac magnetic resonance imaging, confirmed by identification of a novel plakophillin-2 variant. Circulation 2015; 132: e38-40.

https://doi.org/10.1161/CIRCULATIONAHA.115.017284

7. Capriani $A$, bauce $B$, DeLazzari $M$, et al. Arrhythmogenic right ventricular cardiomyopathy. Characterization of left ventricular phenotype and differential diagnosis with dilated cardiomyopathy. J Am Heart Assoc 2020; 9: e014628.

https://doi.org/10.1161/JAMA.119.014628

8. Mirmomen SM, Bradley AJ, Arai AE, et al. Arrhythmogenic left ventricular cardiomyopathy. BJR Case Rep 2020; 12: 6(1)

https://doi.org/10.1259/bjrcr.d20190079

9. Corrado D, Link MS, Calkins H. Arrhythmogenic right ventricular cardiomyopathy. N Eng J Med 2017; 376: 61-72.

https://doi.org/10.156/NEJMra1509267

10. Basso C, Pilichov K, Bauce B, et al. Diagnostic criteria, genetics, and molecular basis of arrhythmogenic cardiomyopathy. Heart Fail Clin 2018; 14(2): 201-213. https://doi.org/10.1016/j.hfc.2018.01.002 11. Mattesi G, Zorzi A, Corrado D, Capriani A. Natural history of arrhythmogenic cardiomyopathy. J Clin Med 2020; 9: 878-891.

https://doi.org/10.3390/jcm9030878

12. Siebermair J, Lehuer S, Sattler SM, et al. Left ventricular innervation assessed by 123I-SPECT/CT is associated with cardiac events in inherited arrhythmia syndromes. Int J Card 2020; S01675273(19): 36249-7. https://doi.org/10.1016/j.ijcard.2020.03.013

13. James CA, Bhonsale A, Tichnell C, et al. Exercise increases age-related penetrance and arrhythmic risk in arrhythmogenic right ventricular dysplasia/cardiomyopathy - associated desmosomal mutation carriers. J Am Coll Cardiol 2013; 62: 1290-1297.

14. Marcus FI, McKenna WJ, Sherill D, et al. Diagnosis of arrhythmogenic right ventricular cardiomyopathy/dysplasia: proposed modification of the task force criteria. Circulation 2010; 121(13): 1533-41. https://doi.org/10.1161/CIRCULATIONAHA.108.80827

15. Corrado D, van Tintelen PJ, McKenna WJ, et al. Arrhythmogenic right ventricular cardiomyopathy: evaluation of the current diagnostic criteria and differential diagnosis. Eur Heart J 2010; 41(14): 14141429. https://doi.org/1.1093/eurheartj/ehz669

16. Clemens M. Hirtelen szívhalál rizikóstratifikáció jobb kamrai car- diomyopathiában. Cardiol Hung 2019; 49: 170-173.

https://doi.org/10.26430/C.HUNGARICA.2019.49.3.170

17. Saguner AM, Brunckhorst C, Duru F Arrhythmogenic ventricular cardiomyopathy: A paradigm shift from right to biventricular disease. World J Cardiol 2014; 6(4): 154-174.

https://doi.org/10.4330/wjc.v6.14.154

18. Sen-Chowdhry S, Prasad SK, Syrris P, et al. Cardiovascular magnetic resonance in arrhythmogenic right ventricular cardiomyopathy revisited. J Am Coll Cardiol 2006; 48: 2132-40.

19. Hirschberg K, Dohy Zs, Tóth A, et al. A mapping technikák által nyújtott lehetőségek a szív MR-vizsgálatok során: indikációk, diagnosztikus érték, limitációk és centrumunk kezdeti tapasztalatai. Cardiol Hung 2020; 50: 45-53.

https://doi.org/10.2264030/C.HUNGARICA.2020.50.1.45

20. Pennell D, Delgado V, Knuuti J et al. The year in cardiology: imaging. Eur Heart J 2020; 41(6): 739-747.

https://doi.org/10.1093/eurheartj/ehz930

21. Haugaa $\mathrm{KH}$, Basso $\mathrm{C}$, Badano LP, et al. Comprehensive multimodality imaging approach in arrhythmogenic cardiomyopathy - an expert consensus document of the European Association of Cardiovascular Imaging. EHJ Cardiovasc Imaging 2017; 18(3): 237-53. https://doi.org/10.1093/ehjci/jew229

22. Smith ED, Lakacwala NK, Papoutsidakis N, et al. Desmoplakin cardiomyopathy, a fibrotic and inflammatory term of cardiomyopathy distinct from typical dilated or arrhythmogenic right ventricular dysplasia. Circulation 2020. May 6.

https://doi.org/10.1161/CIRCULATIONAHA/119.044934

23. Aurogeni SI, Tsarovhas K, Spandidos DA et al Sudden cardiac death in football players: towards a new participation algorhythm. Exp Ther Med 2019; 17: 1143-1148.

https://doi.org/10.3892/etm.2018.7041

24. Drezdner JA, Dvorak j, Kramer EB, et al The FIFA 11 steps to prevent sudden cardiac death during football games. Eur Heart $\mathrm{J}$ 2013; 34: 3594-3595.

25. Baumhäkel M, Kindermann M, Kindermann I, et al. Soccer world championship: a challenge for the cardiologist. Eur Heart J 2007; 28: $150-153$

https://doi.org/10.1093/eurheartj/ehl313 